УДК 343.14

DOI https://doi.org/10.32837/pyuv.v0i4.634

\author{
В. Ю. Первій \\ orcid.org/0000-0003-3131-0610 \\ ад’юнкт кафедри крилінального процесу \\ Дніпропетровського державного університету внутрішніх справ
}

\title{
ДОКАЗУВАННЯ У КРИМІНАЛЬНИХ ПРОВАДЖЕННЯХ ЩОДО ЗЛОЧИНІВ, ПОВ'ЯЗАНИХ ЗІ ЗЛОВЖИВАННЯМ ВЛАДОЮ АБО СЛУЖБОВИМ СТАНОВИЩЕМ: ПОНЯТТЯ ТА ЗМІСТ
}

Вступ. Основою будь-якого кримінального провадження є сукупність фактичних даних, зібраних та оцінених під час досудового розслідування належним чином. Так само відкритим залишається питання стосовно особливостей доказування за фактом вчинення злочинів, пов'язаних зі зловживанням владою або службовим становищем. Актуальною тенденцією в будь-яких дослідженнях має залишатися взаємозв'язок теорії та практики, саме тому неоціненним вкладом у розвиток теорії доказування стосовно службових злочинів $є$ напрацювання певних алгоритмів побудови доказової піраміди й реалізації отриманої інформації практичними працівниками під час розв'язання багатокутних питань у кримінальних провадженнях за фактом зловживання владою або службовим становищем. Повнота досудового розслідування в результаті винайдення всіх фактичних даних, що мають відношення до події конкретного кримінального правопорушення та, як наслідок, покарання винуватих відповідним судовим рішенням, реалізує один із ключових принципів кримінального процесу - принцип невідворотності кримінальної відповідальності.

Метою статті є здійснення всебічного дослідження проблемних аспектів розуміння поняття та змісту доказування в кримінальних провадженнях щодо злочинів, пов'язаних зі зловживанням владою чи службовим становищем, а також детальний аналіз структурних елементів доказування та обставин, що підлягають такому доказуванню.

Аналіз останніх досліджень і публікацій. Питання щодо формування поняття та змісту доказування в кримінальних провадженнях щодо злочинів, пов'язаних зі зловживанням владою або службовим становищем, широко досліджувалося такими науковцями як C.А. Алтухов, M.I. Ануфрієв, О.Ф. Бантишев, В.П. Бахін, Р.С. Бєлкін, О.М. Васильєв, А.Ф. Волобуєв, Б.В. Волженкін, А.В. Галахова, О.Ф. Гіда, В.Г. Гончаренко, Є.В. Додін, А.А. Жижиленко, Б.В. Здравомислов, А.Ф. Зелінський, А.В. Іщенко, В.Ф. Кириченко, В.П. Коваленко, В.О. Коновалова, Г.А. Матусовський, М.М. Михеєнко, В.Ю. Шепітько й іншими вченими. Але, незважаючи на досить високий ступінь розробленості теми, існують питання, які ще не досліджені повною мірою.
Виклад основного матеріалу дослідження. Сучасне кримінальне законодавство містить чимало складів злочинів, за які передбачено відповідні види покарання. Зокрема, 17 розділ Кримінального кодексу України (далі - ККУ) передбачає криміналізовані суспільно небезпечні діяння, які вчиняються у сфері службової та професійної діяльності, пов'язаної з наданням публічних послуг [1]. Власне, ці суспільні відносини й є об'єктом роботи, яка пов'язана з дослідженням процесу доказування та необхідності отримання тих фактичних даних, які надалі утворюватимуть матеріали кримінального провадження стосовно злочинів, пов' язаних зі зловживанням владою або службовим становищем. Для вітчизняної кримінальної практики випадки вчинення вищеназваних злочинів не поодинокі, а тому відбувається i судова практика із цього питання. Таким чином, за перше півріччя 2020 року судами України першої інстанції та Вищим антикорупційним судом було винесено 9 вироків за ч. 1, 2 ст. 364 Кримінального кодексу України (Зловживання владою або службовим становищем) і ст. 364-1 ККУ, 29 вироків за ст. 369-2 ККУ (Зловживання впливом), 3 вироки за ст. 365 ККУ (Перевищення влади або службових повноважень працівником правоохоронного органу), 27 вироків за ст. 366 ККУ (Службове підроблення), 20 вироків за ст. 367 ККУ (Службова недбалість) і 44 вироки за ст. 368 ККУ (Прийняття пропозиції, обіцянки або одержання неправомірної вигоди особою) тощо $[1 ; 2]$.

Поряд із виявленням і кваліфікацією правопорушення, про вчинення якого було повідомлено або самостійно виявлено з будь-якого джерела, виявлення обставин, що можуть свідчити про вчинення кримінального правопорушення слідчим або прокурором, важливим елементом реалізації принципу кримінального процесу - невідворотності кримінальної відповідальності, є проведення досудового розслідування. 3 боку кваліфікації вчинених суспільно небезпечних діянь для подальшого кримінального провадження та вибору варіанту доказування, для встановлення кримінально-правового механізму службового діяння необхідно розглянути:

- чи відбувалося порушення службовою особою зумовлених службовим становищем обов'язків; 
- внаслідок яких дій службової особи була заподіяна істотна шкода державним або суспільним інтересам, що охороняються законом, правам та інтересам громадян, інтересам суб'єктів економічної діяльності тощо;

- чи був причинний зв'язок між злочинним діянням службової особи й наслідками, що наступили [3].

Доцільно зауважити, що для кваліфікації вчиненого кримінального правопорушення 3 метою подальшого досудового розслідування важливе визначення способу такого діяння. Таким чином, використання наданих повноважень, свого становища, застосування наданих повноважень проти покладеного обов'язку й всупереч інтересам служби є загальною ознакою будь-якого зловживання владою або службовим становищем [4].

У процесі дослідження встановлено, що фактично зловживання владою або службовим становищем або ж перевищення службових повноважень (на думку багатьох вітчизняних науковців воно є елементом зловживання владою, а конкретно В.І. Соловйов вважає, що «<...> перевищення службових повноважень мислимо як результат використання службовими особами свого становища $<. . .>$ ») $є$ порушенням службовою особою закону, формальних меж наданих їй прав [5]. У такому випадку корисно звернутися до ч. 2 ст. 19 Конституції України, яка зазначає: «Органи державної влади й органи місцевого самоврядування, їх посадові особи зобов'язані діяти лише напідставі, в межах повноважень тау спосіб, щопередбачені Конституцією та законами України» [6] .

Наголосимо, що доказування - це процес отримання, належного оформлення, оцінки й застосування доказів у рамках кримінального провадження на стадії досудового розслідування за фактом вчинення певного кримінального правопорушення. Докази як фактичні дані спрямовані на відтворення реальної картини подій минулого, тому що діяльність слідчого має ретроспективний характер, а тому чи не єдиним інструментом завжди буде доказова база. Крім того, докази мають вагоме значення в процесі досягнення цілей судочинства й виконання завдань кримінального процесу, тому що від кількості та якості отриманої інформації залежить, наприклад, повнота й швидкість досудового розслідування. На думку більшості видатних вітчизняних вчених-процесуалістів, питання доказів і доказування було й залишається важливим, фактично епіцентром системи кримінального процесу.

У теорії доказів незмінне уявлення про доказування як вид пізнання обставин злочину, тому що вони мають значення в розслідуванні кримінального правопорушення, а емпіричний матеріал, зібраний під час дослідження події правопорушення, становитиме матеріали кри- мінального провадження. Вивчаючи об'єкт дослідження, уповноважені на це службові особи доходять висновку про здатність особи вчинити певний вид суспільно небезпечного діяння або бездіяльності. Таким чином поєднуються всі рівні пізнання - чуттєве й раціональне начала людської оцінки побаченого й відчутого, а також об'єктивізм, притаманний, зокрема, слідчому, прокурору, експерту, спеціалісту тощо.

Відповідно до положень чинного Кримінального процесуального кодексу України (далі - КПК) обов'язок доказування покладається на слідчого, прокурора, а у визначених Кодексом випадках на потерпілого [7]. Проте доречно звернути увагу на те, що саме поняття «обов'язок доказування» можна тлумачити так: обов'язок збирати, перевіряти й оцінювати докази з метою встановлення істини й обов'язок обгрунтовувати свої висновки, посилаючись на отримані фактичні дані в процесі розслідування.

Отже, процес доказування визначається індивідуально по кожному кримінальному провадженню, тому що ситуаціям вчинених суб'єктами кримінальних правопорушень відповідають різні обставини, а тому докази, які необхідно отримати для доведення винуватості тієї чи іншої особи, різняться між собою. Усталеним залишається лише порядок оформлення отриманих доказів із тим, щоб вони були визнані під час судового розгляду допустимими, належними й отриманими законним шляхом.

Те саме стосується і доказування в рамках кримінальних проваджень щодо кримінальних правопорушень, пов'язаних зі зловживанням владою або службовим становищем. На думку багатьох вчених, службові злочини часто мають непростий процес отримання фактичних даних для подальшого долучення до матеріалів кримінального провадження.

Розслідуванню злочинів, пов'язаних зі зловживанням владою або службовим становищем, як і всім іншим видам цієї стадії, притаманна плановість та організованість, що є факторами коефіцієнту корисної дії з'ясування всіх обставин. Дослідження доводить, що процес збирання доказів нерозривно пов'язаний з основними елементами організації розслідування, а саме: побудовою версій, від чого залежить формування необхідності отримання тих чи інших фактичних даних із певних джерел у залежності від змодельованої слідчим ситуації; виходячи зі сформованих версій, службовій особі належить сформувати питання, які підлягатимуть подальшому вивченню, та відшукати обставини, які сприяли зловживанню владою або службовим становищем; визначенням необхідних у кримінальному провадженні слідчих (розшукових) і негласних слідчих (розшукових) дій, що становитимуть значну частку інфор- 
мації, яка надалі представлятиметься доказами в суді. Крім того, не менш важливим для слідчого є встановлення предмета доказування.

Доцільно звернути увагу на те, що для успішного розслідування кримінального правопорушення та покарання винних слідчий, прокурор, слідчий суддя, суд зобов'язані встановити наявність події кримінального правопорушення, його вид, учасників і всі обставини, що мають значення для законного й обгрунтованого розв'язання кримінального провадження, що робиться 3 метою захисту й відновлення порушених прав потерпілих від кримінально караного діяння. Зокрема, це стосується пошуку всіх необхідних доказів, їх належної оцінки й оформлення.

Метою кримінального процесуального пізнання є одержання знання про факти, що підлягають встановленню в кримінальному провадженні. У теорії доказів поняття доказування визначається як соціальне пізнання події минулого за допомогою здійснення певних процесуальних дій або прийняття процесуальних рішень: проведення огляду, допиту, слідчого експерименту, експертного дослідження тощо [8, с. 5].

Доречно зауважити, що процес доказування - це діяльність особливої процесуальної форми. Суб'єкт доказування, який встановлює через докази обставини в кримінальному провадженні, переходить від сприйняття окремих фактів, інформації про них під час проведення окремих процесуальних дій (чуттєво-практичний аспект пізнання) до логічного осмислення сприйнятого (гносеологічний аспект сприйняття) [8, с. 5].

Як зазначалось раніше, дослідження спрямоване на вивчення змісту доказування в злочинах, пов'язаних зі зловживанням владою або службовим становищем. Саме тому необхідно звернути увагу на оцінні поняття, що обов'язково слід встановлювати за конкретними обставинами в кожному кримінальному провадженні за фактом злочинів цього типу. На корисливий мотив та істотну шкоду як базові складові частини об'єктивної сторони суспільно небезпечного діяння звернена увага далі за текстом, а зараз існує потреба схарактеризувати зміст поняття «використання влади чи службового становища всупереч інтересам служби» як не менш важливу складову частину об'єктивної сторони діяння, передбаченого ст. 364 КК України [1].

Під час дослідження вироків за ч. ч. 1, 2 ст. 364 КК України, в яких вказано «всупереч інтересам служби» як один із ключових елементів інкримінування злочину зловживання владою або службовим становищем, і порівнявши тексти вироків Вищого антикорупційного суду у справі № 766/16775/17 від 07 липня 2020 р. і Богородчанського районного суду Івано-Франківської області від 05 серпня 2020 р. тощо, виявлено, що таке словосполучення означає небажання служ- бової особи зважати на покладені на неї законом чи іншим нормативно-правовим актом обов'язки, дії всупереч їм, відхилення будь-яких службових інтересів, які йдуть всупереч особистим інтересам особи. Такі дії незаконні, такі, що не сприяють реалізації цілей і завдань апарату управління відповідного органу, підприємства, установи або організації. Саме для втілення функціоналу цих апаратів і наділяються відповідними повноваженнями службові особи. У випадку нехтування своїми посадовими обов'язками або використання повноважень або їх зловживання можна зазначати, що така особа діє всупереч інтересам служби.

У вироках судів часто йдеться про обов'язковість дослідження та детального вивчення компетенції службової особи, її прав, обов'язків, меж відповідальності для встановлення того, чи належали певні дії до кола її обов'язків, чи мала особа вчинити в інший спосіб та чи були таке рішення, дія чи бездіяльність незаконними. Суди зазначають, що органи досудового розслідування часто нехтують і залишають поза увагою цю невіддільну складову частину об’єктивної сторони [9].

Зловживаючи службовим становищем або наданими їй владними повноваженнями, особа порушує принцип законності, а також методи роботи державного чи громадського апарату, а тому завданням дослідження є доведення факту, що ознака об'єктивної сторони злочинів, пов'язаних зі зловживанням владою або службовим становищем «всупереч інтересам служби», ключова для доказового процесу й інкримінування суспільно небезпечного діяння конкретній особі. Крім того, завжди необхідно звертати увагу на те, який саме нормативний припис порушила особа, діючи всупереч інтересам служби, тому що діяльність будьякої посадової особи регламентується законами, підзаконними нормативно-правовими актами, статутами, посадовими інструкціями, різних видів договорами, а тому, зловживаючи повноваженнями, особа не може не порушити будь-який нормативно-правовий акт, який регулює та визначає вектори посадової діяльності.

3 вищезазначеного випливає, що органи досудового розслідування в кримінальних провадженнях за фактом зловживання владою або службовим становищем зобов'язані з'ясувати межі повноважень, компетенцію посадової особи в конкретному питанні, встановити, чи могла вона вчинити в інший спосіб та який саме нормативно-правовий акт порушено. Зокрема, під час вивчення пункту про порушення конкретного правового припису варто звернути увагу на межі дискреційних повноважень, тобто належним чином дослідити можливість дії особи не з особистого інтересу, а з дозволу закону, який вказує, що службова особа «може», «має право», «на власний розсуд», «встановлює», «визначає» тощо. 
Слід зазначити, що засобами доказування в процесі первинного вивчення матеріалів за фактом правопорушення можуть стати норми закону, які було порушено внаслідок неправомірних дій посадової особи. Власне, така інформація і $є$ підІрунтям для побудови доказової піраміди, адже від неї походитимуть докази, що підтверджують використання влади або службового становища всупереч інтересам служби або істотну шкоду тощо.

Досить важливим моментом у процесі доказування винуватості або невинуватості особи у вчиненні злочину, передбаченого ст. $364 \mathrm{KK}$ України, є дослідження розміру завданої внаслідок неправомірного діяння шкоди, тому що натепер істотна шкода, завдана зловживанням владою або службовим становищем носить виключно майновий характер.

Питання щодо наявності в діях особи складу злочину, передбаченого ст. 364 КК України, має бути чітко встановлено й доведено, що саме вчинення службового злочину стало причиною певних наслідків, які повинні піддаватися грошовій оцінці. Відповідно до диспозиції згаданої статті заподіяні наслідки повинні мати форму прямої дійсної шкоди, тобто шкоди, яка вже настала, є закономірним і необхідним результатом зловживання владою або службовим становищем всупереч інтересам служби.

Разом із цим втрачена вигода, неодержані доходи полягають у позбавленні можливості отримання коштів у майбутньому. Однак слідчий має пам'ятати, що така гіпотетична, можлива лише в майбутньому шкода може бути предметом цивільноправового спору як упущена вигода й не повинна враховуватися як злочинний наслідок.

Від травня 2014 р. змінено примітки 3 і 4 до ст. 364 КК України. Зміна примітки 4 полягає в тому, що в статтях про перевищення влади або службових повноважень, зловживання владою або службовим становищем, службову недбалість істотна шкода або тяжкі наслідки носять суто матеріальний характер. Стосовно такої позиції законодавця досі в наукових колах точаться дискусії та існують думки щодо неправильності такої позиції, тому що, виходячи з обставин конкретної ситуації, істотна шкода може набувати й нематеріального характеру. Незважаючи на це, слідчий як службова особа зобов'язаний діяти в рамках закону, а тому під час збирання та оцінки доказів варто зауважити, що зловживання владою є злочином тоді, коли службова особа, яка його вчинила, заподіяла шкоду у вигляді 100 або більше неоподатковуваних мінімумів доходів громадян (далі - НМДГ) або тяжкі наслідки у вигляді 250 або більше НМДГ [1].

Якщо істотна шкода натепер розуміється виключно як матеріальна категорія, то її необхідно якимось чином вимірювати.
Примітка 3 до ст. 364 КК України: «Істотною шкодою у ст. ст. $364,364^{1}, 365,365^{-2}, 367$ вважається така шкода, яка в сто й більше разів перевищує неоподатковуваний мінімум доходів громадян» [1]. У Перехідних положеннях Податкового кодексу України зазначено, що для цілей застосування всього законодавства України один неоподатковуваний мінімум доходів громадян дорівнює 17 гривень, крім норм адміністративного й кримінального законодавства в частині кваліфікації відповідних правопорушень [10]. У такому випадку розмір завданої шкоди обраховується відповідно до положень про податкову соціальну пільгу (ПСП $=50 \%$ прожиткового мінімуму для працездатних громадян).

Відповідно до чинного на 2020 р. прожиткового мінімуму для працездатних громадян, істотна шкода, завдана суспільно небезпечним діянням, передбаченим ст. 364 КК України, становить:

$2102 / 2=1051$ (грн)

$1051 * 100=105100$ гривень і більше.

Тяжкі наслідки, завдані злочинами, пов'язаними зі зловживанням владою або службовим становищем, становлять:

$1051 * 250=262750$ гривень і більше.

Судовій практиці відомі випадки, коли сторона захисту доводить, що підзахисний, який обвинувачується у вчиненні злочину, пов'язаного зі зловживанням владою або службовим становищем, не є службовою особою, а отже не може бути суб'єктом такого злочину. Пояснюється це тим, що певне підприємство, установа або організація не є державним підприємством, проте переважно суд вважає такі твердження хибними й не бере їх до уваги. Відповідно до ч. 3 ст. 18 КК України, службова особа обіймає посаду, пов'язану з виконанням організаційно-розпорядчих чи адміністративно-господарських функцій тощо [1]. Це вказує на те, що такі ознаки є одними з ключових у понятті службової особи та спільні для багатьох посад як державних органів, так і юридичних осіб приватного й публічного права, осіб, які надають публічні послуги тощо.

Зміст доказування в кримінальних провадженнях за фактом кримінальних правопорушень, пов'язаних зі зловживанням владою або службовим становищем, складається не тільки 3 аналітичного дослідження вищезазначених елементів у вигляді істотної шкоди охоронюваним правам та інтересам, тяжких наслідків, діянні службової особи всупереч інтересам служби, а до того ж містить необхідність збору інших фактичних даних, що надалі є доказами в конкретному провадженні.

Традиційним збором доказової бази за фактом будь-якого кримінального правопорушення є отримання показань зі сторони підозрюваного, обвинуваченого, свідка, потерпілого, експерта стосовно відомих їм обставин, що мають значен- 
ня для подальшого розслідування. Таким чином, показання можуть носити часто корисний інформативний характер. Показання є ідеальними слідами, а тому вони можуть бути як правдивими, так і сумнівними. Це залежить не тільки від добросовісності того, хто їх надає, але й від здібностей людини до запам'ятовування окремих важливих деталей.

Найпоширенішим видом фактичних даних у такому кримінальному провадженні є документ, тому що винуватість або невинуватість особи доводиться стороною обвинувачення шляхом збору документальних підтверджень незаконної діяльності. До таких документів належать: матеріали фотозйомки, відеозапису, матеріали на електронних носіях інформації; носії інформації, на яких зафіксовано процесуальні дії. Матеріали, в яких зафіксовано фактичні дані про протиправні діяння окремих осіб і груп, також є документами й можуть використовуватися в кримінальному провадженні як докази. Доказами в кримінальному провадженні також є фінансово-звітна документація, результати перевірок і довідкова документація.

Як доказовий матеріал використовуються результати експертних досліджень, серед яких судово-економічна експертиза, експертиза комп'ютерної техніки й програмних продуктів тощо.

Кінцевою метою будь-якого кримінального провадження є встановлення об’єктивної істини в ньому. Задля цього необхідне з'ясування обставин, які підлягають доказуванню в кримінальних провадженнях, а також здійснення їх повного й всебічного розгляду.

Висновки $з$ дослідження. Питання щодо формування поняття та змісту доказування в кримінальних провадженнях щодо злочинів, пов' язаних зі зловживанням владою або службовим становищем, актуальне не тільки для науковців, проте й для практичних працівників, особливо це пов'язано з модернізацією законодавства в цьому напрямі. Зміст доказування в кримінальних провадженнях за фактом кримінальних правопорушень, пов'язаних зі зловживанням владою або службовим становищем, складається не тільки з аналітичного дослідження вищезазначених елементів у вигляді істотної шкоди охоронюваним правам та інтересам, тяжким наслідкам, діянні службової особи всупереч інтересам служби, але поряд із цим містить необхідність збору інших фактичних даних, що надалі є доказами в конкретному провадженні.

\section{Jimepamypa}

1. Кримінальний кодекс України : Закон України від 05 квітня 2001 р. № 2341-III (в редакції від 12 вересня 2020 р.) / Верховна Рада України. URL: https://zakon.rada.gov.ua/laws/show/2341-14\#Text (дата звернення: 15.09.2020).
2. Єдиний реєстр судових рішень: офіційний вебсайт. URL: http://reyestr.court.gov.ua/ (дата звернення: 15.09 .2020$)$.

3. Розслідування злочинів у сфері службової діяльності (службові злочини). URL: http://library.nlu. edu.ua/POLN_TEXT/KNIGI/1_DISKI/KRIM/html/ $\%$ D0 \% 93\% D0 $\%$ BB $\%$ D0 \% B0 \% D $0 \%$ B2 \% D0 \% B0_29. htm (дата звернення: 15.09.2020).

4. Анісімов Г.М. Особливості кваліфікації злочинів, що вчиняються шляхом зловживання службовим становищем. Вісник Асоиіацї крилінального права України. 2014. № 2 (3). С. 250-268. URL: http://nauka.nlu.edu.ua/wp-content/uploads/2015/ 07/3_21.pdf (дата звернення: 22.08.2020).

5. Пояснювальна записка до проєкту Закону України «Про внесення змін до Кримінального кодексу України щодо усунення необгрунтованої деталізації кримінально-правових заборон» від 16 лютого 2012 р. № 10072. URL: https://ips.ligazakon.net/document/ GF7RS00A?an=3 (дата звернення: 22.08.2020).

6. Конституція України : Закон України від 28 червня 1996 р. № 254к/96-ВР (у редакції від 01 січня 2020 р.) / Верховна Рада України. URL: https://zakon.rada.gov.ua/laws / show / $254 \%$ D0\% BA $/ 96-\%$ D0\% B2\% D1\% 80\#Text (дата звернення: 22.08.2020).

7. Кримінальний процесуальний кодекс України : Закон України від 13 квітня 2012 р. № 4651-VI (у редакції від 11 вересня 2020 р.) / Верховна Рада України. URL: https://zakon.rada.gov.ua/laws/show/4651-17\# Text (дата звернення: 22.08.2020).

8. Фаринник B.I. Особливості формування доказів та доказування в кримінальному судочинстві України. Харків : Фактор, 2013.96 с.

9. Одинець I.I. Злочин «на власний розсуд». Зa-

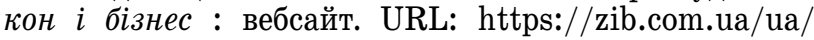
print/136630-diskreciyni_povnovazhennya viklyuchayut_kvalifikaciyu_diy_sl.html (дата звернення: 22.08.20 $\overline{20}$ ).

10. Податковий кодекс України : Закон України від 02 грудня 2010 р. № 2755-VI (у редакції від 13 серпня 2020 р.) / Верховна Рада України. URL: https://zakon.rada.gov.ua/laws/show/2755-17\#Text (дата звернення: 22.08.2020).

\section{Анотація}

Первій В. Ю. Доказування у кримінальних провадженнях щодо злочинів, пов'язаних зі зловживанням владою або службовим становищем: поняття та зміст. - Стаття.

У статті викладено основні положення, які стосуються теорії доказування взагалі й дослідження набору фактичних даних, які повинні бути вивчені уповноваженою службовою особою під час розслідування кримінального провадження за фактом зловживання владою або службовим становищем. Проведено всебічне дослідження проблемних аспектів розуміння поняття доказування в кримінальних провадженнях щодо злочинів, пов'язаних зі зловживанням владою чи службовим становищем, а також детальний аналіз структурних елементів доказування та обставин, що підлягають такому доказуванню. Розкрито особливості доказування за фактом вчинення злочинів, пов'язаних зі зловживанням владою або службовим становищем. Вивчено зміст доказування в злочинах, пов'язаних зі зловживанням владою або службовим становищем, а також звернуто увагу на питання визначення розмірів істотної шкоди й тяжких наслідків. Зазначено, що зміст дока- 
зування в кримінальних провадженнях за фактом кримінальних правопорушень, пов'язаних зі зловживанням владою або службовим становищем, складається не тільки з аналітичного дослідження вищезазначених елементів у вигляді істотної шкоди охоронюваним правам та інтересам, тяжким наслідкам, діянні службової особи всупереч інтересам служби, але поряд із цим містить необхідність збору інших фактичних даних, що надалі є доказами в конкретному провадженні. Авторкою акцентовано увагу, що актуальною тенденцією в будь-яких дослідженнях має залишатися взаємозв'язок теорії та практики. Саме тому неоціненним вкладом у розвиток теорії доказування стосовно службових злочинів є напрацювання певних алгоритмів побудови доказової піраміди й реалізації отриманої інформації практичними працівниками під час розв'язання багатокутних питань у кримінальних провадженнях за фактом зловживання владою або службовим становищем.

Ключові слова: зловживання владою або службовим становищем, доказування, зміст доказування, злочини у сфері службової діяльності, обставини, що підлягають доказуванню, істотна шкода, тяжкі наслідки.

\section{Summary}

Pervii $V$. Yu. Evidence in criminal proceedings of crimes related to abuse of power or official position: concept and content. - Article.

The article sets out the main provisions concerning the theory of evidence in general and the study of actual data to be studied by the authorized official during the investigation of criminal proceedings for abuse of power or official position. A comprehensive study of the problematic aspects of understanding of the concept of evidence in criminal proceedings of crimes related to abuse of power or official position was carried out, as well as a detailed analysis of the structural elements of evidence and the circumstances to be proven. Special features of evidence of committing crimes related to abuse of power or official position are revealed. The content of evidence in crimes related to abuse of power or official position was studied, as well as attention was drawn to the issue of determining the amount of essential damage and heavy consequences. It is noted that the content of evidence in criminal proceedings of crimes related to abuse of power or official position consists not only of analytical studies of the above mentioned elements in the form of essential damage to protected rights and interests, heavy consequences, actions of an appointed official contrary to the interests of the service, but also contains the need to collect other actual data, which are further evidence in a particular proceeding. The author emphasizes that the current trend in any research should remain the coordination of theory and practice. That is why an invaluable contribution to the development of the theory of evidence in relation to official crimes is certain algorithms for developing an pyramid of evidence and realization of the received information by practitioners in solving polygonal questions on criminal proceedings on the fact of abuse of power or official position.

Key words: abuse of power or official position, evidence, content of evidence, crimes in the sphere of official activity, facts to be proven, essential damage, heavy consequences. 